\title{
Review
}

\section{The role of phosphatidylserine in recognition of apoptotic cells by phagocytes}

\author{
Valerie A. Fadok ${ }^{1,2}$, Donna L. Bratton ${ }^{1}$, S. Courtney Frasch ${ }^{1}$, \\ Mary L. Warner ${ }^{1}$ and Peter M. Henson ${ }^{1}$ \\ 1 Department of Pediatrics, National Jewish Medical and Research Center, 1400 \\ Jackson Street, Denver, Colorado 80206 USA \\ 2 corresponding author: tel: 1-303-398-1281 fax: 1-303-398-1381 \\ email: fadokv@njc.org
}

Received: 15.10.97; revised: 23.3.98; accepted: 2.4 .98

Edited by M. Piacentini

\begin{abstract}
Exposure of phosphatidylserine on the outer leaflet of the plasma membrane is a surface change common to many apoptotic cells. Normally restricted to the inner leaflet, phosphatidylserine appears as a result of decreased aminophospholipid translocase activity and activation of a calcium-dependent scramblase. Phosphatidylserine exposure has several potential biological consequences, one of which is recognition and removal of the apoptotic cell by phagocytes. It is still not clear which receptors mediate PS recognition on apoptotic cells; however, several interesting candidates have been proposed. These include the Class B scavenger and thrombospondin receptor CD36, an oxLDL receptor (CD68), CD14, annexins, $\beta 2$ glycoprotein I, gas- 6 and a novel activity expressed on macrophages stimulated with digestible particles such as $\beta$-glucan. Whether PS is the sole ligand recognized by phagocytes or whether it associated with other molecules to form a complex ligand remains to be determined.
\end{abstract}

Keywords: phosphatidylserine; apoptosis; phagocytosis; receptors; membranes

Abbreviations: $\beta 2-\mathrm{GPI}$ : b2-glycoprotein IBMDM: bone marrowderived macrophages; CL: cardiolipin; GPS: glycerophosphorylserine; HMDM: human monocyte-derived macrophages; PC: phosphatidylcholine; PE: phosphatidylethanolamine; PI: phosphatidylinositol; PS: phosphatidylserine; SR: scavenger receptors; TCR: T cell receptor; TSP: thrombospondin; UV: ultraviolet light; $\mathrm{VnR}$ : vitronectin receptor.

Recognition and removal by phagocytes is the final common event in the lives of many apoptotic cells. Apoptotic cells are removed prior to their lysis, suggesting that they express specific surface changes that signal phagocytes to bind and engulf them. These phagocytes can be professional (the macrophages) or amateur (including such cells as fibroblasts, epithelial cells and vascular smooth muscle cells). To date, there have been a number of receptors described for macrophages and other cells which bind to apoptotic cells and mediate their uptake. These include lectin-like receptors (Duvall et al, 1985, Dini et al, 1992; 1995; Hall et al, 1994; Morris et al, 1994; Falasca et al, 1996), the vitronectin receptor $\alpha \mathrm{v} \beta 3$ (Savill et al, 1990; Hall et al, 1994; Hughes et al, 1997), CD36 (Savill et al, 1992), an uncharacterized phosphatidylserine-recognizing receptor (Fadok et al, 1992a,b, 1993; Pradhan et al, 1997), CD14 (Flora and Gregory 1994; Devitt et al, 1998), and scavenger receptors (Sambrano and Steinberg, 1995; Fukasawa et al, 1996; Platt et al, 1996; Murao et al, 1997). The ABC1 transporter, also involved in uptake of mammalian apoptotic cells, has recently been shown to mediate anion transport (Luciani and Chimini, 1996; Becq et al, 1997). It is homologous to the ced-7 gene associated with phagocytosis of apoptotic bodies in C. elegans (Ellis et al, 1991). How any of these receptors mediate phagocytosis of apoptotic cells is not known. In addition, the ligands for these receptors are not well characterized; however, exposure of phosphatidylserine on the external leaflet of the plasma cell membrane appears to be common to many apoptotic cells (Fadok et al, 1992a,b; Schlegel et al, 1993; Mower et al, 1994; Koopman et al, 1994; Bennet et al, 1995; Homburg et al, 1995; Martin et al, 1995a; Shiratsuchi et al, 1997), and this phospholipid appears to be recognized in a stereospecific fashion by subsets of macrophages (Fadok et al, 1992a,b, 1993; Pradhan et al, 1997), by melanoma cells (Fadok, 1995), by smooth muscle vascular cells (Bennett et al, 1995), and by Sertoli cells (Shiratsuchi et al, 1997).

Normally, the phospholipids of the plasma membrane are distributed asymmetrically. Choline-containing lipids, such as phosphatidylcholine (PC) and sphingomyelin, are concentrated on the outer leaflet, whereas the aminophospholipids, including phosphatidylethanolamine (PE) and phosphatidylserine (PS), are present in highest abundance on the inner leaflet. Phosphatidylserine, in fact, is restricted exclusively to the inner leaflet in most cells. Loss of phospholipid asymmetry and exposure of phosphatidylserine was first demonstrated for apoptotic lymphocytes (Fadok et al, 1992a; Schlegel et al, 1993; Mower et al, 1994); however, these findings have been confirmed for a number of cell types, including neutrophils, tumor cell lines, smooth muscle vascular cells, spermatogonia, and Jurkat $T$ cells and their cytoplasts (Fadok et al, 1992b; Bennet et al, 1995; Homburg et al, 1995; Martin et al, 1995a, 1996; Shiratsuchi et al, 1997). Because exposure of phosphatidylserine appears to be a universal feature of apoptotic cells, it is now used as a marker in flow cytometry assays utilizing fluorochrome-labelled annexin V, which binds to PS in a calcium-dependent manner (Vermes et al, 1995; Zhang et al, 1997). 


\section{Mechanisms for phosphatidylserine exposure in apoptotic cells}

The mechanisms for PS exposure on the surface of apoptotic cells appear complex and will remain an active area of investigation for some time. To determine these, an understanding of the maintenance of normal membrane phospholipid asymmetry is required. Two mechanisms have been proposed. A membrane protein termed the aminophospholipid translocase transfers PS and to some extent, PE, from the outer leaflet to the inner leaflet (Devaux, 1991; Zachowski, 1993; Williamson and Schlegel, 1994). This protein appears to be a $\mathrm{Mg}^{2+}$-ATPase which is inhibited by $\mathrm{Ca}^{2+}$ at concentrations achieved in many apoptotic cells (Daleke and Huestis, 1985; Zachowski et al, 1986; Bitbol et al, 1987; Bevers et al, 1989; Morrot et al, 1990; Comfurius et al, 1990; Auland et al, 1994). Tang and coworkers recently cloned a novel P-type ATPase with aminophospholipid translocase activity (Tang et al, 1996). The second mechanism involves the tethering of PS in the inner leaflet by its association with membrane skeletal proteins such as fodrin (non-erythrocyte spectrin), based on the known ability of PS to bind to spectrin (Mombers et al, 1980; Williamson et al, 1987; Maksymiw et al, 1987; Middlekoop et al, 1988). The tethering mechanism fell out of favor for a period of time (see Calvez et al, 1988; Devaux, 1991; Williamson and Schlegel, 1994); for example, Pradhan and coworkers labelled cytoskeletal proteins with a photoactivable analogue of phosphatidylethanolamine (2-(2azido-4-nitrobenzoyl)-1-acyl-sn-glycero-3-phospho $\left[{ }^{14} \mathrm{C}\right]$ ethanolamine) and found no differences in spectrin labelling between normal red cells and PS-expressing red cells from patients with sickle cell anemia (Pradhan et al, 1991). However, the tethering hypothesis appears to be enjoying a resurgence of interest, given the observation that fodrin is cleaved during apoptosis. Other potential intracellular tethering molecules for phosphatidylserine could include annexins or polyamines (Chung et al, 1985; Meers et al, 1986; Bratton, 1994).

Loss of phospholipid asymmetry can be achieved in red cells and platelets by treatment with calcium ionophores. Externalization of PS is rapid, suggesting facilitated transport rather than passive diffusion of lipids across the bilayer. This activity is believed to be mediated by a protein termed a scramblase, which is activated by calcium, is ATP-independent, and is nonspecific with regard to the phospholipids transported (Verhoven et al, 1995; Williamson et al, 1992, 1995). It is believed to be a proteinmediated flip site for the rapid transbilayer movement of phospholipids. The protein has been purified from red cell and platelet membranes, and the gene has recently been cloned (Basse et al, 1996; Comfurius et al, 1996; Zhou et al, 1997). Abnormalities in the function of this protein in vivo mediate the bleeding disorder known as Scott syndrome, in which failure of coagulation results from lack of PS expression on the surface of activated platelets (e.g. see Sims et al, 1989; Kojima et al, 1994; Stout et al, 1997).

Verhoven and coworkers (Verhoven et al, 1995) studied PS exposure in the $T$ cell hybridoma DO11.10 which undergoes activation-induced cell death following anti-CD3 treatment. They utilized NBD-labelled phospholipids to study PS and PC transport during development of apoptosis. They found that prior to the development of nuclear condensation, PS translocation to the inner leaflet was impaired. At the same time, the transport of PC was increased. These data showed for the first time that during apoptosis, aminophospholipid translocase activity was impaired as the scramblase was activated. The net result was PS exposure on the surface of the cell.

We have recently compared the roles of the aminophospholipid translocase and scramblase in three additional cell types known to express PS when undergoing apoptosis: ultraviolet light (UV)-treated HL-60 cells, anti-Fas treated Jurkat $T$ cells, and UV-treated human peripheral blood neutrophils (Bratton et al, 1997). Utilizing NBD-PS uptake as a measure of aminophospholipid translocase activity in both bulk uptake assays and flow cytometric assays, we found that translocase activity was impaired in all three cell types. The increase in NBD-PC uptake by all three cell types supported the notion that scramblase was activated. Changes in these activities preceded the expression of PS, as determined by annexin $\mathrm{V}$ binding. Because both the aminophospholipid translocase activity and the scramblase are reported to be affected by alterations in calcium levels, we studied the effects of $\mathrm{Ca}^{2+}$ depletion on PS exposure. Chelation of intracellular $\mathrm{Ca}^{2+}$ with BAPTA had no effect on PS expression, loss of aminophospholipid translocase activity, or activation of nonspecific phospholipid flip-flop. In contrast, depletion of extracellular $\mathrm{Ca}^{2+}$ was associated with a marked decrease in annexin $\mathrm{V}$ binding (the annexin assay however was done in the presence of $\mathrm{Ca}^{2+}$, as annexin binding is calcium-dependent) and loss of nonspecific phospholipid transport by apoptotic cells. There was no alteration in the percentage of apoptotic cells nor was there restoration of aminophospholipid translocase activity, suggesting that loss of aminophospholipid translocase activity was not sufficient for PS expression on apoptotic cells. Restoration of extracellular $\mathrm{Ca}^{2+}$ levels restored annexin binding and nonspecific phospholipid transport, but the actual levels of PS expressed appeared to be determined by the degree of aminophospholipid translocase impairment. We therefore concluded that nonspecific phospholipid transport (as mediated by the proposed scramblase) is dependent on extracellular $\mathrm{Ca}^{2+}$, which is in agreement with the findings of Hampton et al (1996) in U937 cells. Activation of the scramblase activity appears to be the driving force for PS expression during apoptosis; however, the activity of the aminophospholipid translocase ultimately modulates the degree of PS expression.

The contribution of membrane skeletal changes to exposure of PS remains to be determined. Fodrin is cleaved early in the development of apoptosis (Martin et al, 1995b, 1996; Vanags et al, 1996) by calpain or a similar protease (Squier et al, 1994; Squier and Cohen, 1997). The relationship of this finding to PS exposure is not known at this time, as the inhibitors used in these studies appear to inhibit the entire apoptotic process rather than just fodrin cleavage. One of the central mechanisms believed to mediate many of the changes of apoptosis is the activation of ICE-like proteases termed caspases. The relationship of 
these proteins to apoptosis was first determined in the nematode $C$. elegans, in which the ced-3 gene, which encodes a caspase, was shown to be essential for cell death (Yuan and Horvitz, 1990; Yuan et al, 1993). The role of caspases in the eventual exposure of PS on the surface of the apoptotic cell was first suggested by the findings of Martin et al (1996). They found that the caspase inhibitors ZVAD-FK, YVAD-CK and DEVD-FK prevented CPP 32 activation, fodrin cleavage, and PS expression in anti-Fas treated Jurkat $T$ cells and their cytoplasts. In contrast, Schlegel recently reported that caspase inhibitors had no effect on PS expression induced by glucocorticoids in D010.11 T cell hybridoma cells, although they did inhibit PS expression induced by anti-TCR antibodies (Schlegel et al, 1997). Vanags et al (1996) examined the kinetics of PS exposure, fodrin cleavage, plasma membrane blebbing, and nuclear fragmentation in TNF $\alpha$-treated U937 cells and anti-Fas-treated Jurkat $T$ cells. They could not determine which event occurred first and they were not able to demonstrate uncoupling of the nuclear events from the extranuclear events. They did observe, however, that all events in U937 cells appeared more sensitive to calpain inhibitors than to caspase inhibitors, whereas Jurkat cells appeared more sensitive to caspase inhibitors.

Our own work with apoptotic human neutrophils (Frasch et al, 1998) also supports the notion that regulation of apoptosis and PS expression may be cell and signal specific. Stressful stimuli such as exposure to UV or hyperosmolarity induced DNA fragmentation and PS exposure in neutrophils that was associated with activation of p38 MAPkinase; a p38 MAPkinase inhibitor was found to inhibit nuclear changes of apoptosis (Frasch et al, 1998) PS expression (Frasch, unpublished data). Neither anti-Fas nor spontaneous apoptosis in human neutrophils was inhibited by the p38 MAPK inhibitor. In contrast, caspase inhibitors inhibited nuclear apoptosis and PS expression in stress-induced, anti-Fas, and spontaneous neutrophil apoptosis (Frasch et al, 1998, and unpublished data). If and how the caspases affect the aminophospholipid translocase or the scramblase remains to be determined; however, Schlegel has shown preliminary evidence that the translocase is not cleaved in apoptotic T cells (Schlegel et al, 1997). To summarize then, it appears that caspases are involved in many but not all cells in which PS exposure has been demonstrated; clarification of caspase involvement in PS exposure will require the step-by-step dissection of the pathway between caspase activation and loss of phospholipid asymmetry.

BCL-2 protein, as well as other family members such as $B C L-X_{L}$, are known to inhibit apoptosis in many systems. Their role in regulating membrane changes is not clear. In $\mathrm{T}$ and $\mathrm{B}$ lymphocytic tumor cell lines, overexpression of BCL-2 appears to inhibit PS expression and prevent recognition by macrophages, as well as inhibit nuclear apoptosis (Martin et al, 1995a; Flora et al, 1996). Aged neutrophils overexpressing BCL-2 do not show evidence of nuclear apoptosis; however they are still phagocytosed by macrophages (Lagasse and Weissman, 1994). Whether they express PS remains to be determined, but the data reinforce the notion that membrane changes can be divorced from nuclear changes of apoptosis in some cells.

\section{Recognition of phosphatidylserine by phagocytes}

It has been known for some time that macrophages appear to recognize cells which have lost membrane asymmetry (Fidler et al, 1980; McEvoy et al, 1986; Schlegel and Williamson, 1987; Pradhan et al, 1994); however, a large body of data suggest that macrophages can recognize PS specifically. Several groups of investigators have found that human and rodent macrophages, as well as insect phagocytes, preferentially take up negatively charged liposomes, particularly those containing PS (e.g. Fidler et al, 1980; Schroit and Fidler, 1982; Mehta et al, 1982; Ratner et al, 1986; Allen et al, 1988; Mietto et al, 1989). In addition, human and rodent macrophages (including freshly isolated human alveolar and splenic macrophages, 10-14 day cultured human bonemarrow-derived macrophages, cultured human monocytes, resident and thioglycollate-elicited mouse peritoneal macrophages) can bind to and engulf symmetric red cell ghosts, red cells with PS inserted externally, oxidized red cells, or sickled red cells, all of which express PS externally (Tanaka and Schroit, 1983; Hebbel and Miller, 1984; Schwartz et al, 1985; Connor et al, 1994; Pradhan et al, 1994; Sambrano et al, 1994; Sambrano and Steinberg, 1995). Binding and/or phagocytosis of these PS-expressing red blood cells could be inhibited by preincubation of the macrophages with liposomes containing PS.

This work inspired our search for exposure of PS during apoptosis and for the mechanism by which this phospholipid was recognized. We initially studied the phagocytosis of apoptotic mouse thymocytes by thioglycollate-elicited mouse peritoneal exudate macrophages, which had been

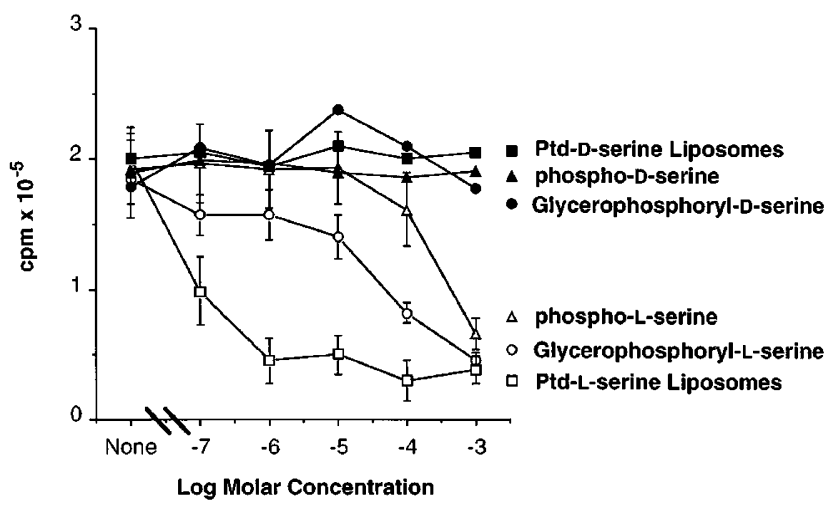

Figure 1 The binding of ${ }^{3} \mathrm{H}$-glycerophosphorylserine to macrophages is inhibited by $\mathrm{L}$, but not $\mathrm{D}$, isomers of phosphatidylserine, glycerophosphorylserine, and phosphoserine. ${ }^{3} \mathrm{H}$-glycerophosphorylserine $\left(10^{-1} \mathrm{M}\right.$ in HBSS $+2 \mathrm{mg} / \mathrm{ml}$ bovine serum albumin) was added to thioglycollate-elicited mouse macrophages adhered to tissue culture plastic in the presence or absence of unlabelled ligands for $30 \mathrm{~min}$ at $37^{\circ} \mathrm{C}$, then washed and lysed. The lysates were incubated overnight in scintillation fluid, then analyzed for radioactivity in a $\beta$-counter. Ptd-D-serine=phosphatidyl-D-serine; Ptd-Lserine $=$ phosphatidyl-L-serine 
demonstrated previously to take up PS and to bind to PSexpressing red cells (Tanaka and Schroit, 1983). Recognition and uptake of apoptotic cells appeared specific for PS: liposomes containing PS inhibited phagocytosis in a dosedependent manner, whereas liposomes containing other anionic phospholipids, such as phosphatidic acid, phosphatidylinositol, or phosphatidylglycerol, had very little effect (Fadok et al, 1992a). More importantly, by utilizing $L$ and $D$ isomers of PS and its structural analogues, we found that inhibition was stereospecific, which supported the notion that macrophages had receptors specific for PS. We performed ligand binding assays on whole macrophages using tritiated glycerophosphorylserine (GPS), a water soluble structural analogue containing the glycerol backbone and phosphoserine head group without the fatty acid side chains. This compound bound to macrophage membranes and its binding was competed successfully by $L$ but not $D$ isomers of PS, GPS and phosphoserine (Figure 1). These data lended further support to the hypothesis that macrophages had a receptor specific for PS.

Savill and coworkers had established that human monocyte-derived macrophages (HMDM) could recognize apoptotic human neutrophils and lymphocytes by virtue of their vitronectin $(\alpha \mathrm{v} \beta 3)$ receptors $(\mathrm{VnR})$ and their Class $\mathrm{B}$ scavenger receptors (CD36, also a receptor for thrombospondin) (Savill et al, 1990, 1992). These receptors bound to thrombospondin (TSP), which served as a bridge between the macrophage and the apoptotic cell. We wondered if the differences in our systems related to the species we studied, the type of macrophage, or the type of apoptotic cell. We did not know the identity of the ligand on the apoptotic cell to which the thrombospondin bound; however, the data were most compatible with a negatively charged ligand (Savill et al, 1989). Because PS has a negative charge, we collaborated to determine if PS could be recognized by both sets of macrophages (Fadok et al, 1992b). We examined the uptake of apoptotic human neutrophils and mouse thymocytes by mouse bone marrow-derived macrophages (BMDM) (similar in many respects to HMDM) and thioglycollate-elicited macrophages. We found that regardless of apoptotic cell type, bone marrow cells were inhibited by RGDS and anti-VnR antibody, but NOT by PS liposomes. In contrast, the exudate cells were inhibited by PS liposomes but not RGDS or anti-VnR antibody. This led us to several conclusions: (1) that PS was probably not the ligand recognized by thrombospondin, CD36, or VnR; (2) that the differences in recognition mechanisms were not determined by differences between mice and humans or between types of apoptotic cells; (3) that recognition appeared to be determined by macrophage phenotype not the type of apoptotic cell. Since that time, however, evidence is accumulating that the picture is, in fact, more complex, and that the type of apoptotic cell may also contribute to which mechanisms are used for its removal. For example, Flora and Devitt with Christopher Gregory, have shown that CD14 is involved in the recognition of apoptotic cells by human monocyte-derived macrophages, but that this mechanism appears to be more efficient for lymphocytes compared to neutrophils (Flora and Gregory, 1994; Devitt et al, 1998). They also have suggested that ICAM-3 plays a role in the recognition of apoptotic lymphocytes by macrophages (Gregory et al, 1995). Lastly, Hart et al (1997) have demonstrated that ligation of CD44 increases uptake of apoptotic neutrophils but not apoptotic lymphocytes.

Because thioglycollate is a proinflammatory stimulus, we wished to test the hypothesis that inflammatory macrophages recognized PS. We also wondered if a macrophage using the VnR-CD36-thrombospondin mechanism could be stimulated to recognize PS. Laszlo et al (1993) had demonstrated that stimulation of mouse BMDM with digestible particulate stimuli such as $\beta$-glucan could induce an increase in lysosomal hydrolases. Noble and coworkers went on to show that these macrophages secreted TGF $\beta$, which was essential to the maturation of the inflammatory phenotype (Noble et al, 1993). We therefore stimulated mouse BMDM with $\beta$-glucan and found that over the next $48 \mathrm{~h}$, inhibition of phagocytosis by RGDS was lost whereas inhibition by PS liposomes was acquired (Fadok et al, 1993). We confirmed these results using PS-expressing red cells in a rosetting assay. PS recognition was induced by digestible particulate stimuli and required the autocrine/ paracrine production of either TGF $\beta$ or PAF (Fadok et al, 1993; Rose et al, 1995). We concluded that the PS receptor was one component of the inflammatory phenotype. Interestingly, although these macrophages no longer used the $\mathrm{VnR}$ receptor to bind and engulf apoptotic cells, there was no decrease in $\mathrm{VnR}$ expression on the cell surface (Fadok et al, 1993).

These findings raised several questions. Investigators studying a variety of human macrophages have shown that they could bind and phagocytose PS-expressing red cells, yet Savill and coworkers were never able to inhibit phagocytosis of apoptotic cells using phospho-L-serine by HMDM or by macrophages isolated from inflammatory sites (Ren and Savill, 1995, Savill, personal communication). We found that human macrophages, like mouse macrophages, required induction to recognize $\mathrm{PS}$ on apoptotic cells (Figure 2). Treating HMDM with digestible particulate stimuli such as $\beta$-glucan, zymosan, or even apoptotic cells (Warner and Fadok, unpublished data) resulted in phagocytosis of apoptotic cells that was inhibited stereospecifically by PS and its analogues, but not by other anionic phospholipids and not by anti-VnR antibodies or RGDS. As we found for the mouse bone marrow-derived macrophages, the addition of exogenous TGF $\beta$ plus latex could also induce PS recognition by these macrophages. The presence of a phagocytic stimulus was essential as TGF $\beta$ alone did not induce PS recognition (Ren and Savill, 1995). These data suggested to us that the PS receptor we proposed for mouse macrophages could also be induced on human macrophages, and led to the development of the model shown in Figure 3.

It is difficult to reconcile the disparities between the reports of human macrophage-mediated uptake of PSexpressing red cells, which is inhibited by PS liposomes, and uptake of apoptotic cells, which is not inhibited by PS liposomes unless the macrophages are stimulated first. One possible explanation is that macrophages do not see PS on the surface of the red cell in the same way that they 


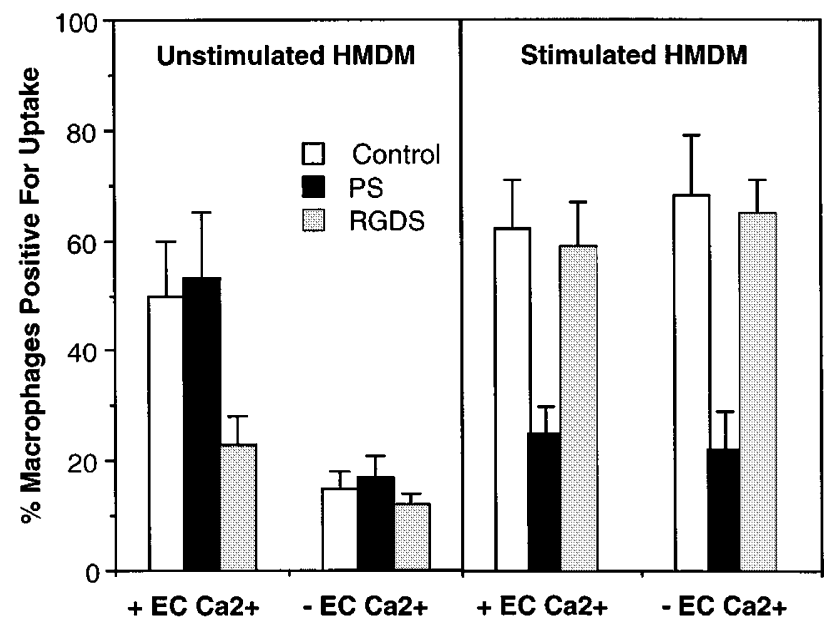

Figure 2 PS-mediated phagocytosis of apoptotic neutrophils by human monocyte-derived macrophages (HMDM) does not depend on extracellular calcium. HMDM were stimulated or not with $\operatorname{TGF} \beta(10 \mathrm{ng} / \mathrm{ml})$ and $\beta$-glucan $(10 \mu \mathrm{g} / \mathrm{ml})$ for $48 \mathrm{~h}$ prior to the phagocytosis assay, which was performed in RPMI (+EC Ca ${ }^{2+}$ ) or $\mathrm{Ca}^{2+}, \mathrm{Mg}^{2+}$ free RPMI with $5 \mathrm{mM}$ EDTA $\left(-\mathrm{EC} \mathrm{Ca}^{2+}\right)$. The preparation of PS-containing liposomes is described in Fadok et al (1992a); total lipid concentration was $0.1 \mathrm{mM}$; RGDS was used at $1 \mathrm{mM}$. Control indicates macrophage uptake in the absence of either inhibitor see it on an apoptotic cell. This hypothesis is supported by the work of Terpstra et al (1997); they found that macrophage binding of PS-expressing oxidized red cells was inhibited by the presence of EDTA, whereas the binding of apoptotic cells was not. Also, we have found that PS-inhibitable uptake by stimulated human macrophages (Figure 2) and thioglycollate-elicited macrophages (Fadok, unpublished data) is not dependent on extracellular $\mathrm{Ca}^{2+}$ or $\mathrm{Mg}^{2+}$; this is in contrast to the $\mathrm{Ca}^{2+}$ and $\mathrm{Mg}^{2+}$ dependence observed for the VnR-CD36-thrombospondin mechanism described by Savill et al (1990). Another possibility is suggested by the work of Pradhan et al (1997); they have attempted to synthesize all these findings in a series of experiments comparing uptake of apoptotic cells by the mouse macrophage cell line $\mathrm{J} 774$ with that by thioglycollate-elicited peritoneal exudate macrophages. They found that uptake of apoptotic cells by $\mathrm{J} 774$ macrophages was inhibited by RGDS and by symmetric red cell ghosts, but not by PS liposomes. In contrast, uptake by the exudate macrophages was inhibited by PS liposomes, but not by symmetric red cell ghosts or RGDS. They proposed that each macrophage type can recognize PS; the macrophages just see it in a different context or in association with a different additional ligand.

\section{The nature of the phosphatidylserine receptor}

It is clear that macrophages can recognize phosphatidylserine in a dose-dependent and stereospecific manner (Mietto et al, 1989; Fadok et al, 1992a) which suggests that a PS receptor exists. As mentioned above, we have identified macrophages

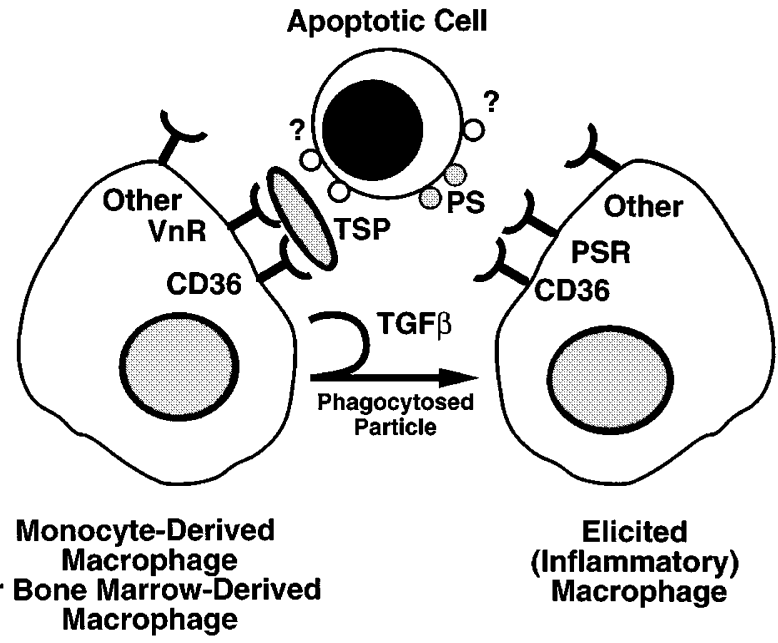

Figure 3 Uptake of particulate stimuli induce the autocrine/paracrine release of TGF $\beta$ and promotes the switch to PS recognition. This simplified model suggests that macrophages which utilize the VnR-CD36-TSP mechanism can be induced to recognise PS by treatment with digestible particulate stimuli, which can include zymosan, $\beta$-glucan, or even apoptotic cells themselves. CD36 appears to be required for uptake by either mechanism. The role of other receptors in this model has not yet been clarified. TSP=thrombospondin

which phagocytose apoptotic cells in a manner inhibited stereospecifically by PS and its structural analogues. Other anionic phospholipids, including phosphatidylinositol, phosphatidylglycerol and phosphatidic acid were inactive (Fadok et al, 1992a). Is this recognition mediated by a unique receptor, or by receptors which have been identified previously? Several receptors have been suggested to play a role in mediating $P S$ recognition, including scavenger receptors, CD68 (an oxLDL receptor), CD14, annexins, $\beta 2$ glycoprotein I and gas-6.

\section{Scavenger receptors}

Some (but not all) of the scavenger receptors (SR) are known to mediate the uptake of PS liposomes (for a review, see Pearson, 1996) and a variety of SR have been implicated in the uptake of apoptotic cells (Savill et al, 1992; Sambrano and Steinberg, 1995; Fukasawa et al, 1996; Platt et al, 1996).

\section{Class A scavenger receptors}

Platt and coworkers showed that the class A macrophage scavenger receptor (SR-A) mediates the uptake of apoptotic thymocytes by mouse thymic macrophages and thioglycollate-elicited peritoneal macrophages. In fact, thymic macrophages from SR-A deficient mice showed a $50 \%$ decrease in uptake of apoptotic thymocytes (Platt et al, 1996). Terpstra and coworkers recently examined the ability of resident peritoneal macrophages from SR-A deficient mice to bind apoptotic thymocytes; they found a $21 \%$ decrease in binding (Terpstra et al, 1997). The ligand recognized by this receptor, however, remains to be 
Table 1 Potential candidates for recognition of phosphatidylserine on apoptotic cells

\begin{tabular}{|c|c|c|c|}
\hline PS-binding protein & Bind PS & $\begin{array}{c}\mathrm{Ca}^{2+} \\
\text { dependence } \\
\text { of } \mathrm{PS} \text { binding }\end{array}$ & $\begin{array}{c}\text { Bind other } \\
\text { anionic } \\
\text { phospholipids }\end{array}$ \\
\hline Class A scavenger receptors & No & Not applicable & No \\
\hline Class B scavenger receptors & Yes & $?^{\mathrm{b}}$ & Yes \\
\hline CD36 & Yes & $?$ & Yes \\
\hline CLA-1 & Yes & $?$ & Yes \\
\hline CD68 & Yes & $\mathrm{No}^{\mathrm{C}}$ & Yes \\
\hline CD14 & $?$ & $?$ & Yes $^{d}$ \\
\hline Annexins & Yes & Yes & Yes \\
\hline$\beta 2$-GPI & Yes & No & Yes \\
\hline Gas-6 & Yes & Yes & Yes \\
\hline Stimulated macrophage $\mathrm{PSR}^{\mathrm{a}}$ & Yes & No & No \\
\hline
\end{tabular}

aPSR (phosphatidylserine receptor) indicates the PS-inhibitable uptake mechanism described by Fadok et al (1992a) in stimulated macrophages (see text). The actual receptor has not been identified. ${ }^{\mathrm{b}} \mathrm{Ca}^{2+}$ dependence was not assessed for the Class $\mathrm{B}$ scavenger receptors (Rigotti et al, 1995; Murao et al, 1997). 'Binding of PS determined by ligand blotting in the presence of EDTA (see Sambrano and Steinberg, 1995). ${ }^{\mathrm{d} O t h e r}$ anionic phospholipids not assessed (Sambrano and Steinberg, 1995).

identified, as the class A SR do not bind phosphatidylserine (Lee et al, 1992).

\section{Class B scavenger receptors}

The Class B scavenger receptors include SRB1 (and its human homologue CLA-1 [CD36 and LIMPII analogous-1]) and CD36. SRB1 can bind to PS liposomes (Rigotti et al, 1995; Fukasawa et al, 1996) and when transfected into $\mathrm{CHO}$ cells can phagocytose apoptotic cells (Fukasawa et al, 1996); however, SRB1 is expressed primarily in liver and steroidogenic tissues (Acton et al, 1996), making it less likely as a candidate for a general macrophage PS receptor. CLA1 is found in the liver and testis; however, it also has been found on circulating monocytes (Murao et al, 1997). When transfected into HEK 293 cells, it facilitated the binding of apoptotic cells, which was inhibited by liposomes containing either PS or PI (Murao et al, 1997). The most interesting potential candidate for PS recognition is the other Class $B$ scavenger receptor CD36, which is also a thrombospondin receptor. CD36 has been implicated in uptake of apoptotic neutrophils by human macrophages (Savill et al, 1992) and has been suggested to mediate the uptake of PS-expressing photoreceptor outer segments (ROS) in retinal pigment epithelium (Ryeom et al, 1996). Rigotti et al (1995) showed that the binding of acLDL to cells transfected with human CD36 was blocked by PS liposomes; however, phosphatidylinositol (PI) was more potent in this assay. The uptake of ROS by retinal pigment epithelium was also inhibited by both PS and PI liposomes, as would be expected for a CD36mediated mechanism (Ryeom et al, 1996). In contrast, we have never observed significant inhibition of phagocytosis of apoptotic cells by PI liposomes in either human or mouse macrophages (Fadok et al, 1992a; and unpublished data). Ren, Navazo and coworkers transfected human CD36 into melanoma cells and COS cells, and showed that phagocytosis of apoptotic cells was upregulated. However, phagocytosis was not inhibited by phospho-L-serine (Ren et al, 1995; Navazo et al, 1996), a ligand we have found effective in both human and mouse macrophages stimulated to recognize PS on apoptotic cells (Fadok et al, 1992a; unpublished data). Unfortunately, the effects of PS liposomes in the CD36-transfected melanoma and COS systems were not examined.

We have attempted to determine the role of CD36 in PS recognition by studying phagocytosis of apoptotic cells by human macrophages stimulated to recognize PS with $\beta$ glucan (Warner et al, unpublished data). Stimulation resulted in a macrophage population whose phagocytosis of apoptotic cells was no longer inhibited by RGDS or antiVnR antibodies, but was inhibited by PS liposomes. Antibodies against C36 inhibited the phagocytosis of either stimulated or unstimulated human macrophages. Flow cytometric analysis showed that particulate stimuli caused the downregulation of $\mathrm{VnR}$ on macrophages from 10 of the 12 donors we have examined; however, CD36 expression remained the same. If macrophages were pretreated with PS liposomes in an attempt to downregulate the PS receptor, the binding of anti-CD36 monoclonal antibodies was not decreased. PS liposomes also did not compete with the antibody for binding to CD36. These data suggested to us that CD36 was not the PS-recognizing receptor in our system. If, however, CD36 was downregulated by incubating the cells on antibody-coated plates, phagocytosis was reduced and PS inhibition was no longer statistically significant. These data, together with our observations that phosphatidylinositol-containing liposomes did not inhibit phagocytosis, suggested to us that CD36 did not recognize PS directly, but that it did cooperate with our proposed PS receptor (see Figure 3), perhaps in a fashion similar to that proposed for its cooperation with VnR (Savill et al, 1992).

\section{CD68 (oxidized LDL receptor)}

Sambrano and Steinberg (1995) have shown that the 94$97 \mathrm{kd}$ oxLDL receptor found on resident peritoneal macrophages may mediate uptake of apoptotic cells. This oxLDL receptor is identical to mouse macrosialin or its human homologue CD68 (Ramprasad et al, 1995). The oxLDL 
receptor appeared to mediate the recognition of apoptotic cells and phagocytosis was inhibited by PS liposomes (Sambrano and Steinberg, 1995). Direct binding of PS liposomes to a 94-97 kd band from macrophage membrane preparations was also demonstrated (Sambrano and Steinberg, 1995). In our studies of human macrophages, surface expression of CD68 was not detectable by flow cytometry, and anti-CD68 antibodies did not inhibit phagocytosis of apoptotic cells (Warner et al, unpublished data). These data suggest that, although CD68 may mediate binding to PS on apoptotic cells, it is not the only receptor to do so, as CD68negative macrophages can also phagocytose apoptotic cells in a PS-inhibitable manner.

\section{CD14}

The antigen identified by monoclonal antibody 61D3 has been shown to be involved in phagocytosis of apoptotic lymphocytes by human macrophages, and has recently been identified as CD14 (Flora et al, 1994; Devitt et al, 1998). Soluble CD14 has been shown to bind directly to phosphatidylinositol and to a fluorescent derivative of phosphatidylethanolamine, and it has been suggested to be a soluble shuttle for lipids (Yu et al., 1997). Two pieces of preliminary evidence from the laboratories of Willamson and Schlegel have suggested that CD14 might recognize PS on apoptotic cells (Callahan et al, 1997). First, removal of CD14 from the surface of $J 774$ cells (a mouse macrophage line) with phospholipase $\mathrm{C}$ resulted in decreased phagocytosis of apoptotic cells and lipid-symmetric red cell ghosts. Second, an LPS-resistant variant of $\mathrm{J} 774$, which lacks functional CD14, showed reduced capacity to phagocytose apoptotic cells or symmetric red cell ghosts. Direct demonstration of PS binding to CD14 is still required, particularly demonstration of the ability of CD14 to mediate binding to PS on a cell surface.

\section{Annexins}

Annexins comprise a group of proteins which bind to phospholipids in the presence of $\mathrm{Ca}^{2+}$ (Reutelingsperger and van Heerde, 1997; Swairjo and Seaton, 1994). In fact, this property has been exploited to develop a rapid and simple assay for the assessment of PS exposure on apoptotic cells (Vermes et al, 1995; Zhang et al, 1997). Pryzdial and coworkers have some intriguing data to suggest that annexin II can mediate the binding of herpes viruses to host cells. They found that cytomegalovirus and herpes simplex types 1 and 2 expressed phosphatidylserine on their surfaces, which facilitated the association of human annexin II to virus particles within human fibroblasts (Sutherland et al, 1997; Wright et al, 1995; Pryzdial and Wright, 1994). They were able to inhibit viral infection of human fibroblasts with a rabbit antiserum raised against human annexin II, suggesting that annexin II might facilitate the uptake of these viruses. Is it possible that annexins could mediate the binding of apoptotic cells to phagocytes? Although primarily intracellular in location, some annexins can be found in the blood and extracellular spaces (Reutelingsperger and van Heerde, 1997). Our studies with human and mouse macrophages suggest that annexins are unlikely candidates for mediating the binding of apoptotic cells, as PS-inhibitable uptake is not lost in the absence of $\mathrm{Ca}^{2+}$ (Figure 2). Furthermore, preliminary experiments showed that anti-annexin $\mathrm{V}$ did not inhibit uptake of apoptotic neutrophils by human monocytederived macrophages, whether they were stimulated to recognize PS or not (Fadok, unpublished data). Reutelingsperger and van Heerde (1997) have made the intriguing suggestion that annexins, in fact, may help control coagulation in inflammatory sites in vivo by binding to the procoagulant surfaces of apoptotic cells.

\section{B2-glycoprotein I}

$\beta 2$-glycoprotein I ( $\beta 2-\mathrm{GPI})$ is a serum protein believed to regulate coagulation. It binds to anionic phospholipids such as cardiolipin, phosphatidylserine, phosphatidylglycerol, phosphatidylinositol, and phosphatidic acid (Balasubramanian et al, 1997), and forms an important epitope for many of the 'anticardiolipin' and 'anti-phospholipid' antibodies identified in patients with the antiphospholipid antibody syndrome (aPL) (Roubey, 1996). Price et al (1996) showed that antiphospholipid antibodies from patients with primary aPL or aPL associated with systemic lupus erythematosus could opsonize apoptotic cells in the presence of $\beta 2-\mathrm{GPI}$. Subsequently, Balasubramanian et al (1997) showed that the binding of $\beta 2$-GPI to apoptotic cells or lipid-symmetric red cells, followed by the binding of anti- $\beta 2$-GPI, facilitated uptake into macrophages. $\beta 2 \mathrm{GPI}$ alone was able to increase the uptake of symmetric red cells by $50 \%$; however, uptake of apoptotic thymocytes was only slightly enhanced in the absence of the opsonizing antibody. These data suggest that PS on apoptotic cells could contribute to FcR-mediated uptake in patients with the appropriate autoantibodies; this would be expected to be a proinflammatory pathway which would contribute to the disease process, as uptake of opsonized apoptotic cells results in the release of proinflammatory cytokines and lipid mediators (Meagher et al, 1992; Stern et al, 1996; Fadok et al, 1998).

\section{Gas-6}

Gas-6, the product of growth arrest-specific gene 6 (Manfioletti et al, 1993), is the newest potential candidate for mediating the binding of macrophages to PS on apoptotic cells. It is a soluble protein related to protein $\mathrm{S}$, a negative regulator of coagulation, and has been shown to mediate the binding of U937 cells (a human histiocytic line) to PS-coated ELISA plates in the presence of $\mathrm{Ca}^{2+}$ (Nakano et al, 1997). Nakano and coworkers have made the intriguing suggestion that gas 6 might mediate the binding of PS-expressing cells to phagocytes. Gas- 6 binds to a set of unique receptor tyrosine kinases (axl, sky and mer) which contain extracellular domains similar to those found in cell adhesion molecules (Varnum et al, 1995; Nagata et al, 1996). Axl mRNA expression has been demonstrated by PCR in normal human bone marrow and at low levels in peripheral blood monocytes; treatment of human monocytes with IFN $\alpha$ was associated with upregulation of message (Neubauer et al, 1994). Whether gas- 6 is involved in the uptake of apoptotic cells by macrophages remains to be determined. If so, gas- 6 may 
serve as a bridging molecule between the apoptotic cell and the macrophage, in a manner similar to that observed for thrombospondin.

To summarize our thoughts, then, on the nature of PS receptor in macrophages, we believe that the phagocytic activity we have described, the uptake of apoptotic cells which is inhibited stereospecifically by PS and its structural analogues, GPS and phospho-L-serine; which is not inhibited by other negatively charged phospholipids, polyanions, or acLDL; and which is expressed on macrophages stimulated with digestible particulate stimuli, is distinct from the currently described scavenger receptors and CD14, and has not been identified to date. This activity can be removed from the surface of the macrophages with proteases. Incubation with PS liposomes inhibits its function with maximal inhibition reached by $20 \mathrm{~min}$ after addition of the liposomes, followed by recovery of phagocytic activity $24 \mathrm{~h}$ later. We also believe that the activity we have described is not likely to be mediated by annexins or gas- 6 , as the binding of those proteins to PS requires $\mathrm{Ca}^{2+}$ and phagocytosis by $\mathrm{PS}$ recognizing macrophages (which we define strictly as inhibition by PS liposomes) is not inhibited in the absence of calcium. We think that $\beta 2$-GPI would most likely facilitate phagocytosis in diseased states where autoantibodies are produced, rather than in the normal state. What seems likely is that multiple PS-recognizing receptors exist; determining how they may interact, what exactly they see and when they operate, is a critical objective.

Lastly, there is also some evidence to suggest that amateur phagocytes can recognize PS on apoptotic cells. Vascular smooth muscle cells phagocytose their apoptotic counterparts in a manner inhibited by preincubation with PS liposomes or with annexin V (Bennett et al, 1995). Neither $\mathrm{PI}$ liposomes nor anti-annexin $\mathrm{V}$ antibodies inhibited phagocytosis in this system, suggesting that neither the known scavenger receptors nor annexins were mediating phagocytosis by vascular smooth muscle cells. In contrast, the recognition of spermatogenic cells by Sertoli cells was inhibited by PS-, PI- and CL-containing liposomes (Shiratsuchi et al, 1997), suggesting the use of a different receptor from that used by stimulated macrophages or vascular smooth muscle cells. However, phagocytosis by Sertoli cells was also inhibited by glycerophosphorylserine and weakly by phospho-L-serine, whereas phospho-Dserine had no effect, suggesting some stereospecificity.

\section{The biological consequences of PS expression}

What does exposure of PS on the outer leaflet of an apoptotic cell mean, from a biological point of view? We favor it as a recognition ligand for rapid removal; however, it is not clear at this point what the role of $P S$ as a recognition ligand is in vivo and whether all macrophages, in fact, see it. There must be other ligands on the apoptotic cell in addition to PS. The early work of Duvall and coworkers suggested changes in surface carbohydrates (Duvall et al, 1985); most recently Falasca and coworkers have shown increased expression of mannose, $\mathrm{N}$ acetylgalactose, and possibly galactose on the surface of apoptotic cells (Falasca et al, 1996). However, the ligands which mediate the binding of thrombospondin to apoptotic cells remain to be determined. It is intriguing to speculate that loss of membrane phospholipid asymmetry may facilitate exposure of these ligands as well.

Exposure of PS on cell surfaces has other potential biological consequences. It has been known for some time that PS serves as a cofactor for the coagulation cascade (Zwaal and Schroit, 1997), and there is a small but growing body of evidence to suggest that PS can have a variety of anti-inflammatory or immunosuppressive effects. In his recent review, Kornbluth (1994) cited a number of instances in which PS could inhibit macrophage parasiticidal activity and cytokine production, as well as lymphocyte proliferation and cytokine production. More recently, two different groups of investigators (Aramaki et al, 1996; DiNapoli et al, 1997) have shown that phosphatidylserine-containing liposomes inhibited transcription of inducible nitric oxide synthase and nitric oxide production in mouse macrophages stimulated with LPS. Phagocytosis of apoptotic cells by non-FcR mediated uptake mechanisms not only fails to stimulate inflammatory mediator production in normal human macrophages (Meagher et al, 1992; Stern et al, 1996) but also inhibits inflammatory mediator production stimulated by LPS or zymosan (Voll et al, 1997; Fadok et al, 1998). Perhaps PS is one of the inhibitory signals found on apoptotic cells. Lastly, exposure of PS on the surface of apoptotic cells may contribute to the inflammation and coagulation defects seen in patients with systemic lupus erythematosus and primary aPL by binding autoantibodies in the presence of proteins such as $\beta 2 \mathrm{GPI}$ (see section on $\beta 2 \mathrm{GPI}$ above).

\section{Conclusions}

It seems clear that exposure of phosphatidylserine is a common feature on apoptotic cells and that it serves as a recognition signal for phagocytosis by at least a subset of macrophages. Several questions remain. How is this phospholipid recognized? In particular, how does the macrophage get past the glycocalyx to access this lipid? There are two potential clues. First, there appears to be an alteration of surface carbohydrates on apoptotic cells (Falasca et al, 1996). Second, Casciola-Rosen et al (1996) have shown by confocal microscopy that annexin $\mathrm{V}$ binding is strongest on the surface of small membrane blebs, suggesting the appearance of domains. Is PS recognized on its own merits or is it seen in conjunction with another ligand, such as a protein or carbohydrate? If PS expression is a critical recognition signal, why do not all macrophages appear to recognize it? Is inhibition by PS liposomes too strict a definition, as has been suggested by the work of Pradhan et al (1997)? Perhaps in addition to signalling phagocytosis on its own, loss of phospholipid asymmetry promotes the exposure of other apoptotic ligands. Is there a receptor specific for PS or are multiple receptors (including the scavenger receptors) capable of recognizing this lipid on apoptotic cells? It seems most likely that multiple receptors could bind PS, but whether they can recognize it on a cell surface remains to be determined. How does PS exposure 
contribute to the biological effects of phagocytosis of apoptotic cells, which include suppression of proinflammatory mediator release? These questions will provide fruitful research for us and other 'phagocytophilic' investigators in the coming years.

\section{Acknowledgements}

We would like to thank John Savill, Christopher Gregory and Patrick Williamson for their critical reading of this manuscript and for their many helpful suggestions and insights.

\section{References}

Acton S, Rigotti A, Landschulz KT, Xu S, Hobbs HH and Krieger M (1996) Identification of scavenger receptor SR-B1 as a high density lipoprotein receptor. Science 271: $518-520$

Allen TM, Williamson P and Schlegel RA (1988) Phosphatidylserine as a determinant of reticuloendothelial recognition of liposome models of the erythrocyte surface. Proc. Natl. Acad. Sci USA 85: 8067-8071

Aramaki Y, Nitta F, Matsuno R, Morimura Y and Tsuchiya S (1996) Inhibitory effects of negatively charged liposomes on nitric oxide production from macrophages stimulated by LPS. Biochem. Biophys. Res. Commun. 220: 1-6

Auland ME, Roufogalis BD, Devaux PF and Zachowski A (1994) Reconstitution of ATP-dependent aminophospholipid translocation in proteoliposomes. Proc. Natl. Acad. Sci. USA 91: 10938-10942

Balasubramanian K, Chandra J and Schroit AJ (1997) Immune clearance of phosphatidylserine-expressing cells by phagocytes. J. Biol. Chem. 272:3111331117

Basse F, Stout JG, Sims PJ and Wiedmer T (1996) Isolation of an erythrocyte membrane protein that mediates $\mathrm{Ca} 2+$-dependent transbilayer movement of phospholipid. J. Biol. Chem. 271: 17205-17210

Bennett MR, Gibson DF, Schwartz SM and Tait JF (1995) Binding and phagocytosis of apoptotic vascular smooth muscle cells is mediated in part by exposure of phosphatidylserine. Circ. Res. 77: 1136-1142

Becq F, Hamon Y, Bajetto A, Gola M, Verrier B and Chimini G (1997) ABC1, an ATP binding cassette transporter required for phagocytosis of apoptotic cells, generates a regulated anion flux after expression in Xenopus laevis oocytes. J. Biol. Chem. 272: 2695-2699

Bevers EM, Tilly RHJ, Senden JMG, Comfurius P and Zwaal RFA (1989) Exposure of endogenous phosphatidylserine at the outer surface of stimulated platelets is reversed by restoration of aminophospholipid translocase activity. Biochem. 28: $2382-2387$

Bitbol M, Fellmann P, Zachowski A and Devaux PF (1987) Ion regulation of phosphatidylserine and phosphatidylethanolamine outside-inside translocation in human erythrocytes. Biochim. Biophys. Acta 904: 268-282

Bratton DL (1994) Polyamine inhibition of transbilayer movement of plasma membrane phospholipids in the erythrocyte ghost. J. Biol. Chem. 269: 2251722523

Bratton DL, Fadok VA, Richter DA, Kailey JM, Guthrie LA and Henson PM (1997) Appearance of phosphatidylserine on apoptotic cells requires calcium-mediated nonspecific flip-flop and is enhanced by loss of the aminophospholipid translocase. J. Biol. Chem. 272: 26159-26165

Callahan MK, Krahling SA, Williamson P and Schlegel RA (1997) The role of CD14 in the recognition and phagocytosis of apoptotic thymocytes by macrophages. Mol. Biol. Cell 8 Suppl: $147 a$ (abstract)

Calvez J-Y, Zachowski A, Hermann A, Morrot G and Devaux PF (1988) Asymmetric distribution of phospholipids in spectrin-poor erythrocyte vesicles. Biochem. 27: $5666-56670$

Casciola-Rosen L, Rosen A, Petri M and Schlissel M (1996) Surface blebs on apoptotic cells are sites of enhanced procoagulant activity: implications for coagulation events and antigen spread in systemic lupus erythematosus. Proc. Natl. Acad. Sci. USA 93: 1624-1629

Chung L, Kaloyanides G, McDaniel R, McLaughlin A and McLaughlin S (1985) Interaction of gentamicin and spermine with bilayer membranes containing negatively charged phospholipids. Biochem. 24: 442-452
Comfurius P, Senden JMG, Tilly RHJ, Schroit AJ, Bevers EM and Zwaal RFA (1990) Loss of membrane phospholipid asymmetry in platelets and red cells may be associated with calcium-induced shedding of plasma membrane and inhibition of aminophospholipid translocase. Biochim. Biophys. Acta 1026: 153-160

Comfurius $\mathrm{P}$, Williamson $\mathrm{P}$, Smeets EF, Schlegel RA, Bevers EM and Zwaal RFA (1996) Reconstitution of phospholipid scramblase activity from human blood platelets. Biochem. 35: 7631-7634

Connor J, Pak CC and Schroit AJ (1994) Exposure of phosphatidylserine in the outer leaflet of human red blood cells. Relationship to cell density, cell age, and clearance by mononuclear cells. J. Biol. Chem. 269: 2399-2404

Daleke DL and Huestis WH (1985) Incorporation and translocation of aminophospholipids in human erythrocytes. Biochem. 24: 5406-5416

Devaux PF (1991) Static and dynamic lipid asymmetry in cell membranes. Biochemistry 30: 1163-1173

Devitt A, Raykundalia C, Moffatt OD, Capra JD, Simmons DL and Gregory CD (1998) Human CD14 mediates recognition and phagocytosis of cells undergoing apoptosis. Nature. In press

DiNapoli MR, Calderon CL and Lopez DM (1997) Phosphatidyl serine is involved in the reduced rate of transcription of the inducible nitric oxide synthase gene in macrophages from tumor-bearing mice. J. Immunol. 158: 1810-1817

Dini L, Autuori F, Lentini A, Oliverio S and Piacentini M (1992) The clearance of apoptotic cells in the liver is mediated by the asialoglycoprotein receptor. FEBS Lett. 296: $174-178$

Dini L, Lentini A, Diez GD, Rocha M, Falasca L, Serafino L and Vidal-Vanaclocha F (1995) Phagocytosis of apoptotic bodies by liver endothelial cells. J. Cell Science 108: $967-973$

Duvall E, Wyllie AH and Morris RG (1985) Macrophage recognition of cells undergoing programmed cell death (apoptosis). Immunol. 56: 351-358

Ellis RE, Jacobson DM and Horvitz HR (1991) Genes required for the engulfment of cell corpses during programmed cell death in Caenorhabditis elegans. Genetics 129: $79-94$

Fadok VA, Voelker DR, Campbell PA, Cohen JJ, Bratton DL and Henson PM (1992a) Exposure of phosphatidylserine on the surface of apoptotic lymphocytes triggers specific recognition and removal by macrophages. J. Immunol. 148: 2207-2216

Fadok VA, Savill JS, Haslett C, Bratton DL, Doherty DE, Campbell PA and Henson PM (1992b) Different populations of macrophages use either the vitronectin receptor or the phosphatidylserine receptor to recognize and remove apoptotic cells. J. Immunol. 149: 4029-4035

Fadok VA, Laszlo DJ, Noble PW, Weinstein L, Riches DWH and Henson PM (1993) Particle digestibility is required for induction of the phosphatidylserine recognition mechanism used by murine macrophages to phagocytose apoptotic cells. J. Immunol. 151: 4274-4285

Fadok VA (1995) Recognition of apoptotic cells by professional and amateur phagocytes. J. Cellular Biochem. S19B: 262

Fadok VA, Konowal A, Freed PW, Westcott JY, Bratton DL and Henson PM (1998) Macrophages that have ingested apoptotic cells in vitro inhibit proinflammatory cytokine production through autocrine/paracrine mechanisms involving TGF $\beta$, PGE2, and PAF. J. Clin. Invest. 101: 890-898

Falasca L, Bergamini A, Serafino A, Balabaud C and Dini L (1996) Human Kupffercell recognition and phagocytosis of apoptotic peripheral blood lymphocytes. Exp. Cell. Res. 224: 152-162

Fidler IJ, Raz A, Fogler WE, Kirsh R, Bugelski P and Poste G (1980) Design of liposomes to improve delivery of macrophage-augmenting agents to alveolar macrophages. Cancer Res. 40: 4460-4466

Flora PK and Gregory CD (1994) Recognition of apoptotic cells by a human macrophages: inhibition by a monocyte/macrophage specific monoclona antibody. Eur. J. Immunol. 24: 2625-2632

Flora PK, Devitt A, Johnson GD, Milner AE and Gregory CD (1996) Bcl-2 delays macrophage engulfment of human $B$ cells induced to undergo apoptosis. Eur. J. Immunol. 26: 2243-2247

Frasch SC, Nick JA, Fadok VA, Bratton DL, Worthen GS and Henson PM (1998) p38 MAP kinase-dependent and -independent intracellular signal transduction pathways leading to apoptosis in human neutrophils. J. Biol. Chem. In press

Fukasawa M, Adachi H, Hirota K, Tsujimoto M, Arai H and Inoue K (1996) SRB1, a class $B$ scavenger receptor, recognizes both negatively charged liposomes and apoptotic cells. Exp. Cell. Res. 222: 246-250

Gregory CD, Flora PK, Bhogal HS and De Smet W (1995) Phagocytic clearance of apoptotic cells: novel pathways identified by monoclonal antibodies to cell surface components. J. Cell. Biochem. Suppl. 19B: 312 (abstract) 
Hall SE, Savill JS, Henson PM and Haslett C (1994) Apoptotic neutrophils are phagocytosed by fibroblasts with participation of the fibroblast vitronectin receptor and involvment of a mannose/fucose-specific lectin. J. Immunol. 153: 3218-3227

Hampton MB, Vanags DM, Porn-Ares MI and Orrenius S (1996) Involvement of extracellular calcium in phosphatidylserine exposure during apoptosis. FEBS Letts. 399: 277-282

Hart SP, Dougherty GJ, Haslett C and Dransfield I (1997) CD44 regulates phagocytosis of apoptotic neutrophil granulocytes, but not apoptotic lymphocytes, by human macrophages. J. Immunol. 159: 919-925

Hebbel RP and Miller WJ (1984) Phagocytosis of sickle erythrocytes: immunologic and oxidative determinants of hemolytic anemia. Blood 64: 733-741

Homburg CHE, de Haas M, von dem Borne AEJKr, Verhoeven AJ, Reutelingsperger CPM and Roos D (1995) Human neutrophils lose their surface Fc $\gamma$ RIII and acquire annexin $\mathrm{V}$ binding sites during apoptosis in vitro. Blood 85: 532-540

Hughes J, Liu Y, Van Damme J and Savill J (1997) Human glomerular mesangial cell phagocytosis of apoptotic neutrophils. J. Immunol. 158: 4389-4397

Kojima H, Newton-Nash D, Weiss HJ, Zhao J, Sims PJ and Wiedmer T (1994) Production and characterization of transformed B-lymphocytes expressing the membrane defect of Scott syndrome. J. Clin. Invest. 94: 2237-2244

Koopman G, Reutelingsperger CPM, Kuijten GAM, Keehnen RMJ, Pals ST and van Oers MHJ (1994) Annexin V for flow cytometric detection of phosphatidylserine expression on B cells undergoing apoptosis. Blood 84: 1415-1420

Kornbluth RS (1994) The immunological potential of apoptotic debris produced by tumor cells and during HIV infection. Immunol. Letts. 43: 125-132

Lagasse E and Weissman IL (1994) Bcl-2 inhibits apoptosis of neutrophils but not their engulfment by macrophages. J. Exp. Med. 179: 1047-1052

Laszlo DJ, Henson PM, Remigio LK, Weinstein L, Sable C, Noble PW and Riches DWH (1993) Development of functional diversity in mouse macrophages. Mutual exclusion of two phenotypic states. Am. J. Pathol 143: 587-597

Lee KD, Pitas RE and Papahadjopoulos D (1992) Evidence that the scavenger receptor is not involved in the uptake of negatively charged liposomes by cells. Biochim. Biophys. Acta 1111: 1-6

Luciani M-F and Chimini G (1996) The ATP binding cassette transporter ABC1, is required for the engulfment of corpses generated by apoptotic cell death. EMBO J. 15: $226-235$

Maksymiw R, Sui S-F, Gaub H and Sackmann E (1987) Electrostatic coupling of spectrin dimers to phosphatidylserine containing lipid lamellae. Biochem. 26: 2983-2990

Manfioletti G, Brancolini C, Avanzi G and Schneider C (1993) The protein encoded by a growth arrest-specific gene (gas6) is a new member of the vitamin-K dependent proteins related to protein $\mathrm{S}$, a negative coregulator in the blood coagulation cascade. Mol. Cell. Biol. 13: 4976-4985

Martin SJ, ReutelingspergerCPM, McGahon AJ, Rader JA, van Schie RCAA, LaFace DM and Green DR (1995a) Early redistribution of plasma membrane phosphatidylserine is a general feature of apoptosis regardless of the initiating stimulus: inhibition by overexpression of bcl-2 and abl. J. Exp. Med. 182: 15451556

Martin SJ, O'Brien GA, Nishioka WK, McGahon AJ, Mahboubi A, Saido T and Green DR (1995b) Proteolysis of fodrin (non-erythroid spectrin) during apoptosis. J. Biol. Chem. 270: 6425-6428

Martin SJ, Finucane DM, Amarante-Mendes GP, O'Brien GA and Green DR (1996) Phosphatidylserine externalization during CD95-induced apoptosis of cells and cytoplasts requires ICE/CED-3 protease activity. J. Biol. Chem. 271: 2875328756

McEvoy L, Williamson P and Schlegel RA (1986) Membrane phospholipid asymmetry as a determinant of erythrocyte recognition by macrophages. Proc. Natl. Acad. Sci. USA 83: 3311-3315

Meagher LC, Savill J, Baker A, Fuller RW and Haslett C (1992) Phagocytosis of apoptotic neutrophils does not induce macrophage release of thromboxane B2. J. Leuk Biol. 52: 269-273

Meers P, Hong K, Bentz J and Papahadjopoulos D (1986) Spermine as a modulator of membrane fusion: interactions with acidic phospholipids. Biochem 25: $3109-$ 3118

Mehta K, Lopez-Berestein G, Hersh EM and Juliano RL (1982) Uptake of liposomes and liposome-encapsulated muramyl dipeptide by human peripheral blood monocytes. J. Reticuloendothelial Soc. 32: 155-164
Middlekoop E, Lubin BH, Bevers EM, Op den Kamp JAF, Comfurius P, Chiu DT-Y Zwaal RFA, van Deenan LLM and Roelofsen B (1988) Studies on sickled erythrocytes provide evidence that the asymmetric distribution of phosphatidylserine in the red cell membrane is maintained by both ATP-dependent translocation and interaction with membrane skeletal proteins. Biochim. Biophys. Acta 937: 281-288

Mietto L, Boarato E, Toffano G and Bruni A (1989) Internalization of phosphatidylserine by adherent and non-adherent rat mononuclear cells. Biochim. Biophys. Acta 1013: 1-6

Mombers C, De Gier J, Demel RA and Van Deenen LLM (1980) Spectrinphospholipid interaction. A monolayer study. Biochim. Biophys. Acta 603: 5262

Morris RG, Hargreaves AD, Duvall E and Wyllie AH (1984) Hormone-induced cell death. 2. Surface changes in thymocytes undergoing apoptosis. Am. J. Pathol. 115: $426-436$

Morrot G, Zachowski A and Devaux PF (1990) Partial purification and characterization of the human erythrocyte Mg2+-ATPase. FEBS Letts. 266: 29-32

Mower DA, Peckham DW, Illera VA, Fishbaugh JK, Stunz LL and Ashman RF (1994) Decreased membrane phospholipid packing and decreased cell size precede DNA cleavage in mature mouse B cell apoptosis. J. Immunol. 152: 4832-4842

Murao K, Terpstra V, Green SR, Kondratenko N, Steinberg D and Quehenberger 0 (1997) Characterization of CLA-1, a human homologue of rodent scavenger receptor $\mathrm{BI}$, as a receptor for high density lipoprotein and apoptotic thymocytes. J. Biol. Chem. 272: 17551-17557

Nagata K, Ohashi K, Nakano T, Arita H, Zong C, Hanafusa H and Mizuno K (1996) Identification of the product of growth arrest-specific gene 6 as a common ligand for axl, sky, and mer receptor tyrosine kinases. J. Biol. Chem. 271:30022-30027

Nakano T, Ishimoto Y, Kishino J, Umeda M, Inoue K, Nagata K, Ohashi K, Mizuno K and Arita $\mathrm{H}$ (1997) Cell adhesion to phosphatidylserine mediated by a product of growth arrest-specific gene 6. J. Biol. Chem. 272: 29411-29414

Navazo MDP, Daviet L, Savill J, Ren Y, Leung LLK and McGregor JL (1996) Identification of a domain (155-183) on CD36 implicated in the phagocytosis of apoptotic neutrophils. J. Biol. Chem. 271: 15381-15385

Neubauer A, Fiebeler A, Graham DK, O'Bryan JP, Schmidt CA, Barckow P, Serke S, Siegert W, Snodgrass HR, Huhn, D and Liu ET (1994) Expression of axl, a transforming receptor tyrosine kinase, in normal and malignant hematopoiesis. Blood 84: 1931 - 1941

Noble PW, Henson PM, Lucas C, Mora-Worms M, Carre PC and Riches DWH (1993) Transforming growth factor- $\beta$ primes macrophages to express inflammatory gene products in response to particulate stimuli by an autocrine/paracrine mechanism. J. Immunol. 151: 979-989

Pearson AM (1996) Scavenger receptors in innate immunity. Current Opin. Immunol 8: $20-28$

Platt N, Suzuki H, Kurihara Y, Kodama T and Gordon S (1996) Role for the class A macrophage scavenger receptor in the phagocytosis of apoptotic thymocytes in vitro. Proc. Natl. Acad. Sci. USA 93: 12456-12460

Pradhan D, Williamson P and Schlegel RA (1991) Bilayer/cytoskeleton interactions in lipid-symmetric erythrocytes assessed by a photoactivable phospholipid analogue. Biochem. 30: 7754-7758

Pradhan D, Williamson P and Schlegel RA (1994) Phosphatidylserine vesicles inhibit phagocytosis of erythrocytes with a symmetric distribution of phospholipids. Mol. Membr. Biol. 11: 181-188

Pradhan D, Krahling S, Williamson P and Schlegel RA (1997) Multiple systems for recognition of apoptotic lymphocytes by macrophages. Mol. Biol. Cell 8: 767 778

Price BE, Rauch J, Shia MA, Walsh MT, Liegerthal W, Gilligan HM, O'Laughlin T, Koh JS and Levine JS (1996) Anti-phospholipid autoantibodies bind to apoptotic, but not viable, thymocytes in a $\beta 2$-glycoproteind I-dependent manner. J. Immunol. 157: $2201-2208$

Pryzdial EL and Wright JF (1994) Prothrombinase assembly on an enveloped virus: evidence that the cytomegalovirus surface contains procoagulant phospholipid. Blood 84: $3749-3757$ 
Ramprasad MP, Fischer W, Witztum JL, Sambarno GR, Quehenberger $O$ and Steinberg D (1995) The 94- to 97-kDa mouse macrophage membrane protein that recognizes oxidized low density lipoprotein and phosphatidylserine-rich liposomes is identical to macrosialin, the mouse homologue of human CD68. Proc. Natl. Acad. Sci USA 92: 9580-9584

Ratner S, Schroit AJ, Vinson SB and Fidler IJ (1986) Analogous recognition of phospholipids by insect phagocytes and mammalian macrophages. Proc. Soc. Exp. Biol. Med. 182: 272-276

Ren Y and Savill J (1995) Proinflammatory cytokines potentiate thrombospondinmediated phagocytosis of neutrophils undergoing apoptosis. J. Immunol. 154: 2366-2374

Ren Y, Silverstein RL, Allen J and Savill J (1995) CD36 gene transfer confers capacity for phagocytosis of cells undergoing apoptosis. J. Exp. Med. 181: 1857-1862

Reutelingsperger CPM and van Heerde WL (1997) Annexin V, the regulator of phosphatidylserine-catalyzed inflammation and coagulation during apoptosis. Cell. Mol. Life Sci. 53: 527-532

Rigotti A, Acton SL and Krieger M (1995) The Class B scavenger receptors SR-B1 and CD36 are receptors for anionic phospholipids. J. Biol. Chem. 270: 162116224

Rose DM, Fadok VA, Riches DWH, Clay KL and Henson PM (1995) Autocrine/ paracrine involvement of platelet-activating factor and transforming growth factor- $\beta$ in the induction of phosphatidylserine recognition by murine macrophages. J. Immunol. 155: 5819-5825

Roubey RAS (1996) Immunology of the antiphospholipid syndrome. Arth. Rheum. 39: $1444-1454$

Ryeom SW, Silverstein RL, Scotto A and Sparrow JR (1996) Binding of anionic phospholipids to retinal pigment epithelium may be mediated by the scavenger receptor CD36. J. Biol. Chem. 271: 20536-20539

Sambrano GR, Parthasarathy S and Steinberg D (1994) Recognition of oxidatively damaged erythrocytes by a macrophage receptor with specifity for oxidized low density lipoprotein. Proc. Natl. Acad. Sci. USA 91: 3265-3269

Sambrano G and Steinberg D (1995) Recognition of oxidatively damaged and apoptotic cells by an oxidized low density lipoprotein receptor on mouse peritoneal macrophages: role of membrane phosphatidylserine. Proc. Natl. Acad. Sci. USA 92: 1396-1400

Savill JS, Henson PM and Haslett C (1989) Macrophage phagocytosis of aging neutrophils in inflammation. Programmed cell death in the neutrophil leads to its recognition by macrophages. J. Clin. Invest. 83: 865-875

Savill J, Dransfield I, Hogg N and Haslett C (1990) Vitronectin receptor-mediated phagocytosis of cells undergoing apoptosis. Nature 343: 170-173

Savill JS, Hogg N, Ren Y and Haslett C (1992) Thrombospondin cooperates with CD36 and the vitronectin receptor in macrophage recognition of neutrophils undergoing apoptosis. J. Clin. Invest. 90: 1513-1522

Schlegel RA and Williamson P (1987) Membrane phospholipid organization as a determinant of blood cell-reticuloendothelial cell interactions. J. Cell. Physiol. 132: $381-384$

Schlegel RA, Stevens M, Lumley-Sapanski K and Williamson P (1993) Altered lipid packing identifies apoptotic thymocytes. Immunol. Letts. 36: 283-288

Schlegel RA, Krahling S, Verhoven B and Williamson P (1997) Regulation of phosphatidylserine exposure, a phagocyte recognition signal, in ICE-proteasedependent and -independent apoptosis. Keystone Symposium on Apoptosis and Programmed Cell Death. p7 (abstract)

Schroit AJ and Fidler IJ (1982) Effects of liposome structure and lipid composition on the activation of the tumoricidal properties of macrophages by liposomes containing muramyl dipeptide. Cancer Res. 42: 161-167

Schwartz RS, Tanaka Y, Fidler IJ, Chiu DT-Y, Lubin B and Schroit AJ (1985) Increased adherence of sickled and phosphatidylserine-enriched human erythrocytes to cultured human peripheral blood monocytes. J. Clin. Invest. 75: $1965-1972$

Shiratsuchi A, Umeda M, Ohba Y and Nakanishi Y (1997) Recognition of phosphatidylserine on the surface of apoptotic spermatogenic cells and subsequent phagocytosis by Sertoli cells of the rat. J. Biol. Chem. 272: 23542358

Sims PJ, Wiedmer T, Esmon CT, Weiss HJ and Shattil SJ (1989) Assembly of the platelet prothrombinase complex is linked to vesiculation of the platelet plasma membrane. Studies in Scott syndrome: an isolated defect in platelet procoagulant activity. J. Biol. Chem. 264: 17049-17057

Squier MKT, Miller ACK, Malkinson AM and Cohen JJ (1994) Calpain activation in apoptosis. J. Cell. Physiol. 159: 229-237
Squier MKT and Cohen JJ (1997) Calpain, an upstream regulator of thymocyte apoptosis. J. Immunol. 158: 3690-3697

Stern M, Savill J and Haslett C (1996) Human monocyte-derived macrophage phagocytosis of senescent eosinophils undergoing apoptosis. Mediation by avb3/CD36/thrombospondin recognition mechanism and lack of phlogistic response. Am. J. Pathol. 149: 911-921

Stout JG, Basse F, Luhm RA, Weiss HJ, Wiedmer T and Sims PJ (1997) Scott syndrome erythrocytes contain a membrane protein capable of mediating $\mathrm{Ca} 2+$ dependent transbilayer migration of membrane phospholipids. J. Clin. Invest. 99: $2232-2238$

Sutherland MR, Raynor CM, Leenknegt H, Wright JF and Pryzdial EL (1997) Coagulation initiated on herpesviruses. Proc. Natl. Acad. Sci. USA 94: 1351013514

Swairjo MA and Seaton BA (1994) Annexin structure and membrane interactions: a molecular perspective. Annu. Rev. Biophys. Biomol. Struct. 23: 193-213

Tanaka Y and Schroit AJ (1983) Insertion of fluorescent phosphatidylserine into the plasma membrane of red blood cells. Recognition by autologous macrophages. J. Biol. Chem. 258: 11335-11343

Tang X, Halleck MS, Schlegel RA and Williamson P (1996) A subfamily of P-type ATPases with aminophospholipid transporting activity. Science 272: 14951497

Terpstra V, Kondratenko N and Steinberg D (1997) Macrophages lacking scavenger receptor A show a decrease in binding and uptake of acetylated low-density lipoprotein and of apoptotic thymocytes, but not of oxidatively damaged red blood cells. Proc. Natl. Acad. Sci. 94: 8127-8131

Vanags DM, Porn-Ares MI, Coppola S, Burgess DH and Orrenius S (1996) Protease involvement in fodrin cleavage and phosphatidylserine exposure in apoptosis. J. Biol. Chem. 271: 31075-31085

Varnum BC, Young C, Elliot G, Garcia A, Bartley TD, Fridell Y-W, Hunt RW, Trall G, Clogston C, Toso RJ, Yanaglhara D, Bennett L, Sylber M, Merewether LA, Tseng A, Escobar E, Liu ET and Yamano HK (1995) Axl receptor tyrosine kinase stimulated by the vitamin K-dependent protein encoded by growth-arrestspecific gene 6 . Nature $373: 623-626$

Verhoven B, Schlegel RA and Williamson P (1995) Mechanisms of phosphatidylserine exposure, a phagocyte recognition signal, on apoptotic $T$ lymphocytes. J. Exp. Med. 182: 1597-1601

Vermes I, Haanen C, Steffens-Nakken H and Reutelingsperger CPM (1995) A novel assay for apoptosis. Flow cytometric detection of phosphatidylserine expression on early apoptotic cells using fluorescein labelled annexin V. J. Immunol. Methods 184: 39-51

Voll RE, Herrmann M, Roth EA, Stach C and Kalden JR (1997) Immunosuppressive effects of apoptotic cells. Nature 390: $350-351$

Williamson P, Antia R and Schlegel RA (1987) Maintenance of membrane phospholipid asymmetry. Lipid cytoskeletal interactions or lipid pump? FEBS Letts. 219: 316-320

Williamson P, Kulick A, Zachowski A, Schegel RA and Devaux PF (1992) Ca2+ induces transbilayer redistribution of all major phospholipids in human erythrocytes. Biochem. 31: 6355-6360

Williamson P and Schlegel RA (1994) Back and forth: the regulation and function of transbilayer phospholipid movement in eukaryotic cells (review). Mol. Membr. Biol. 11: 199-216

Williamson P, Bevers EM, Smeets E, Comfurius P, Schegel RA and Zwaal RFA (1995) Continuous analysis of the mechanism of activated transbilayer lipid movement in platelets. Biochem. 34: 10448-10455

Wright JF, Kurosky A, Pryzdial EL and Wasi S (1995) Host cellular annexin II is associated with cytomegalovirus particles isolated from cultured human fibroblasts. J. Virol. 69: 4784-4791

Yu B, Hailman E and Wright SD (1997) Lipopolysaccharide binding protein and soluble CD14 catalyze exchange of phospholipids. J. Clin. Invest. 99: 315-324

Yuan J and Horvitz HR (1990) The Caenorhabditis elegans genes ced-3 and ced-4 act cell autonomously to cause programmed cell death. Dev. Biol. 138: 33-41

Yuan J, Shaham S, Ledoux S, Ellis HM and Horvitz HR (1993) The C. elegans cell death gene ced-3 encodes a protein similar to mammalian interleukin-1 betaconverting enzyme. Cell 75: 641-652

Zachowski A, Favre E, Cribier S, Herve P and Devaux PF (1986) Outside-inside translocation of aminophospholipids in the human erythrocyte membrane is mediated by a specific enzyme. Biochem 25: $2585-2590$

Zachowski A (1993) Phospholipids in animal eukaryotic membranes: transverse asymmetry and movement. Biochem. J. 294: 1-14 
Zhang G, Gurtu V, Kain SR and Yan G (1997) Early detection of apoptosis using a fluorescent conjugate of annexin V. Biotechniques 23: 525-531

Zhou Q, Zhao J, Stout JG, Luhm RA, Wiedmer T and Sims PJ (1997) Molecular cloning of human plasma membrane phospholipid scramblase. A protein mediating transbilayer movement of plasma membrane phospholipids. J. Biol. Chem. 272: $18240-18244$
Zwaal RFA and Schroit AJ (1997) Pathophysiologic implications of membrane phospholipid asymmetry in blood cells. Blood 89: 1121-1132 